\title{
EFFECT OF AGE AT FIRST CALVING AND FIRST LACTATION MILK YIELD ON PRODUCTIVE LIFE TRAITS OF SYRIAN SHAMI COWS
}

\author{
O. Almasri ${ }^{1}$, S. Abou-Bakr ${ }^{2}$ and M. A. M. Ibrahim ${ }^{2}$ \\ 1- General Commission for Scientific Agricultural Research, Damascus, Syria, 2- Department of Animal \\ Production, Faculty of Agriculture, Cairo University, Giza, Egypt \\ Corresponding author: obaidaalimasri@gmail.com
}

Received: 1/4/2020 Accepted: 23/4/2020

\section{SUMMARY}

The objective of this research was to study the effect of age at first calving (AFC) and first lactation milk yield (FMY) on productive life traits of Syrian Shami cows. In this study, the complete records from birth to voluntary culling were collected on 605 cows during the period from 1981 to 2010 at Deir al-Hajar station in Syria. Data were analysed using the General Linear Model (XLSTATE, 2019). The least squares means for AFC and FMY were $30.9 \pm 0.16$ months and $1203 \pm 34 \mathrm{~kg}$, respectively.

The optimum AFC was $\leq 25$ months to achieve the maximum lifetime milk yield, productive life and number of calvings. Increasing AFC (especially over 31.8 months) decreased lifetime milk production, lifetime daily milk yield, productive life and the number of lactations. First lactation milk yield reflected the production capacity in subsequent lactations. The first calvers of more than $1900 \mathrm{~kg}$ produced high milk yield during their life and had shorten dry periods. While cows that produced less than $600 \mathrm{~kg}$ milk in the first lactation had the lowest life time milk production.

\section{Keywords: Age at first calving, First lactation milk yield, Productive life traits, Syrian Shami cows}

\section{INTRODUCTION}

Rearing replacement heifers need a large cost without profitability till starting their productive life. In general, cows become economically beneficial in the second lactation, because in first lactation their bodies and udder tissues had not reached full development (Sawa, 2011).

Age at first calving (AFC) is influenced by management conditions and cow health. Successful management and adequate nutrition during the rearing period of heifers lead to reaching heifers proper body weight and target AFC. Poor feeding during rearing period delay AFC (Wathes et al., 2008). Otherwise, increasing feeding during the rearing period, resulting in heavier heifers and bad body condition score, may be increased infertility and culling rate (Wu et al., 2012).

Evans et al. (2006) stated that heifers calved at first time between 25 - 26 months had a high fertility and short calving interval in subsequent lactations. However, reducing AFC less than 22 months cause increasing the dystocia and decreasing milk production in subsequence lactations (Hoffman et al, 2006). While increasing AFC to 29 months increased replacement costs by $14 \%$, and reduced productive life, lifetime milk yield and number of calvings (Tozer and Heinrichs, 2001).

Janus and Borkowska (2004) showed a negative correlation between first lactation milk yield and productive life traits, so the high first lactation milk yield may affect negatively on the health and growth of cows, and resulted in early culling of cows from the herd.

Productive life is an important trait after milk production that used in selection. This trait is related to productive and reproductive performance and health, and it is affected by management conditions (Krpalkova et al., 2017). Increasing productive life reduced costs of replacement, increased lifetime milk production and number of calvings (Caetano et al., 2017).

No available papers or researches were found related to productive life traits of native Syrian Shami cows. Therefore, the main objective of this study was to investigate the effect of age at first calving and first lactation milk yield on productive life traits of native Syrian Shami cows.

\section{MATERIALS AND METHODS}

Data:

Data used in this study were collected from 605 complete records of 605 Shami cows from birth to voluntary culling dates. These records covered a period of 30 years from 1981 to 2010, belonging to Deir al-Hajar station in Syria. Each record contained the data of age at first lactation, first lactation milk yield, productive life, lifetime milk production and number of lactations for each cow under study.

\section{Herd management:}

Animals were raised under free housing system in semi-closed sheds with concrete floors. Cows were fed twice a day on roughages (straw and cotton seed hulls). Commercial concentrates formulated in station, in addition to hay (vetch, barley and alfalfa) and green fodder, if available, were offered to cows. Water was available all days. Heifers were naturally mated for the first time when reached 18 months old taking into account the weight of the animal $(270 \mathrm{~kg})$. Cows were machine milked twice a day at 06.00 a.m. and 6.00 p.m. The new born calves suckled their 
dams after calving till weaning at 90 days. Milk production was recorded twice a month (Bi-monthly milk recording system) to calculate monthly and total milk yield for each cow.

\section{Studied traits:}

1. Productive life $(\mathrm{PL}$, months $)=$ culling date - first calving date.

2. Lifetime milk production (LMP, $\mathrm{kg}$ ) = cumulated total milk yield produced through productive life of cow.

3. Lifetime daily milk yield (LDMY, $\mathrm{kg}$ ) = lifetime milk production/ number of days from birth to culling for each cow.
4. Number of lactations $=$ total number of lactations during productive life of cow.

\section{Statistical analysis:}

In order to determine the effect of age at first calving on the productive life traits, heifers were classified into five groups according to their average of AFC depending on the standard deviation distribution of AFC as indicated in table (1):

Concerning the effect of first lactation milk yield on the same traits, cows were classified according to their average first lactation milk yield (FMY) into five groups depending on the standard deviation distribution of FMY as presented in table (2):

Table 1. Distribution of heifers according to their average age at first calving

\begin{tabular}{cccc}
\hline Groups & Avg. AFC (mo.) & Min. (mo.) & Max. (mo.) \\
\hline 1 & 23.4 & 20 & 25.4 \\
2 & 27.4 & 25.5 & 28.6 \\
3 & 30 & 28.7 & 31.7 \\
4 & 33.1 & 31.8 & 34.7 \\
5 & 37.2 & 34.8 & 39.9 \\
\hline
\end{tabular}

No. of heifers $=605$

Table 2. Distribution of cows according to their first lactation milk yield

\begin{tabular}{cccc}
\hline Groups & Avg. FMY (kg) & Min. (kg) & Max. $(\mathrm{kg})$ \\
\hline 1 & 507 & 450 & 559 \\
2 & 832 & 560 & 1119 \\
3 & 1361 & 1120 & 1679 \\
4 & 2011 & 1680 & 2400 \\
5 & 2977 & 2420 & 3925 \\
\hline
\end{tabular}

No. of cows $=605$

Data were subjected to statistical analysis of variance, using the General Linear Model of XLSTAT 2019.1.2.56963program.

The statistical model was:

$Y_{i j k l m}=\mu+A_{i}+T_{j}+Y_{k}+S_{l}+(A \times T)_{i j}+e_{i j k l m}$

Where:

$Y_{i j k l m}=$ the observation of the studied traits,

$\mu=$ the overall mean,

$\mathrm{A}_{\mathrm{i}}=$ the fixed effect of $\mathrm{i}^{\text {th }}$ age at first calving (i=1, 2, 3, 4, 5),

Where: $1=\leq 25.4,2=25.5-28.6, \quad 3=28.7-31.7$, $4=31.8-34.7$ and $5=\geq 34.8$ months,

$\mathrm{T}_{\mathrm{j}}=$ the fixed effect of $\mathrm{j}^{\text {th }}$ first lactation milk yield $(\mathrm{j}=1,2,3,4,5)$, Where: $1=<560 \mathrm{~kg}, 2=560-1119$, $3=1120-1679,4=1680-2400$ and $5=>2400 \mathrm{~kg}$, $\mathrm{Y}_{\mathrm{k}}=$ the fixed effect of $\mathrm{k}^{\mathrm{th}}$ year of calving for first lactation $(\mathrm{k}=1,2,3,4,5,6)$, Where:

$1=1981-1985,2=1986-1990, \quad 3=1991-1995$,

$4=1996-2000,5=2001-2005$ and $6=2006-2010$,
$\mathrm{S}_{1}=$ the fixed effect of $1^{\text {th }}$ season of calving for first lactation $(1=1,2,3,4)$, where $1=$ winter, $2=$ spring, $3=$ summer and $4=$ autumn,

$(\mathrm{A} \times \mathrm{T})_{\mathrm{ij}}=$ the effect of the interaction between $\mathrm{i}^{\text {th }}$ age at first calving and $\mathrm{j}^{\text {th }}$ first lactation milk yield, and

$\mathrm{e}_{\mathrm{ijklm}}=$ the experimental error.

The simple correlation coefficients between each of age at first calving and first lactation milk yield and the studied traits were estimated using the XLSTAT 2019.1.2.56963.

\section{RESULTS AND DISCUSSION}

Productive life $(P L)$ :

The least squares means (LSM) and standard errors of productive life (PL) are presented in table (3). The overall mean of the productive life was $67 \pm 1.35$ months, which was longer than that found by Abou-Bakr (2009, 47.5 mo.), Sawa and Bogucki 
(2017, 37.4 mo.) and Kučević et al., (2019, 40.2 mo.) on Holstein cows.

Table 3. Least squares means and standard error (LSM \pm SE) of productive life (PL) in months

\begin{tabular}{|c|c|}
\hline Classification $^{1}$ & $\begin{array}{c}\text { productive life (PL, months) } \\
(\mathrm{LSM} \pm \mathrm{SE})\end{array}$ \\
\hline Overall mean & $67 \pm 1.35$ \\
\hline Age at first calving (month) & $* *$ \\
\hline$\leq 25.4$ & $76.3^{\mathrm{b}} \pm 5.54$ \\
\hline $25.5-28.6$ & $69.3^{\mathrm{b}} \pm 3.05$ \\
\hline 28.7-31.7 & $68^{\mathrm{b}} \pm 2.44$ \\
\hline $31.8-34.7$ & $64.9^{\mathrm{ab}} \pm 3.12$ \\
\hline$\geq 34.8$ & $56.3^{\mathrm{a}} \pm 3.33$ \\
\hline First lactation milk yield (kg) & NS \\
\hline$<560$ & $65.8^{\mathrm{a}} \pm 2.89$ \\
\hline $560-1119$ & $67.4^{\mathrm{a}} \pm 2.70$ \\
\hline $1120-1679$ & $71.1^{\mathrm{a}} \pm 3.20$ \\
\hline $1680-2400$ & $63.4^{\mathrm{a}} \pm 3.36$ \\
\hline$>2400$ & $67.1^{\mathrm{a}} \pm 4.62$ \\
\hline Year of calving (periods) & $* *$ \\
\hline $1981-1985$ & $77.3^{\mathrm{c}} \pm 3.74$ \\
\hline $1986-1990$ & $77.1^{\mathrm{c}} \pm 3.88$ \\
\hline $1991-1995$ & $67.1^{\mathrm{b}} \pm 3.62$ \\
\hline $1996-2000$ & $63.7^{\mathrm{b}} \pm 3.73$ \\
\hline $2001-2005$ & $67.4^{\mathrm{b}} \pm 3.12$ \\
\hline 2006-2010 & $49.2^{\mathrm{a}} \pm 3.28$ \\
\hline Season of calving & NS \\
\hline Winter & $64.8^{\mathrm{a}} \pm 3.23$ \\
\hline Spring & $66.6^{\mathrm{a}} \pm 2.70$ \\
\hline Summer & $67.3^{\mathrm{a}} \pm 2.84$ \\
\hline Autumn & $69.2^{\mathrm{a}} \pm 3.04$ \\
\hline
\end{tabular}

1=within each classification, means not followed by the same letter differ significantly at $5 \%$ level;

Number of records $=605 ; * *(\mathrm{p}<0.01) ; \mathrm{NS}=$ not significant.

The effect of age at first calving (AFC) was highly significant $(\mathrm{p}<0.01)$ on $\mathrm{PL}$, the longest $\mathrm{PL}$ $(76 \pm 5.54$ months) was that of heifers calved at $\leq 25.4$ months, then it decreased gradually with increasing AFC till it reached $56 \pm 3.33$ months for cows that had AFC more than or equal 34.8 mo. This could be due to those cows calved early started productive life early, so they had longer PL compared to those calved late, in addition, there is a negative correlation between age at first calving and productive life. Sawa et al. (2019) and Curran et al., (2013) arrived at the same conclusion on Holstein cows in Poland and
USA, respectively. Sawa and Bogucki (2010) indicated cows had AFC $\leqslant 22$ months had the longest productive life.

Coffey et al. (2006) explained that a share of Holstein genes in the population of Polish dairy cows increased growth rate of heifers and probably they reached the body weight and body condition score desired for breeding at a youngerage. Zavadilová and Štípková (2013) concluded that Holstein cows in Czech had AFC greater than 33 months had a lower probability to show oestrus or conceive, so those 
cows were culled early and had a shorter productive life.

While, Ojango et al. (2005) reported a nonsignificant effect of AFC on productive life on Holstein cattle in Kenya.

The effect of first lactation milk yield (FMY) on PL was nonsignificant (table 3), which may be due to that native Syrian Shami cows are normally low milk producers and short lactating animals. This result is in agreement with Brzozowski et al., (2003) on Polish Black and White cows. Januś and Borkowska (2012) on Holstein-Friesian cows in Poland and Herlihy et al. (2013) on dairy cows in Ireland, who found a negative correlation between productive and reproductive traits, and added that cows of high FMY had low fertility and short productive life.

\section{Number of lactations (NL), Lifetime milk production (LMP) and Lifetime daily milk yield (LDMY) :}

The least squares means of number of lactations (NL), lifetime milk production (LMP) and lifetime daily milk yield (LDMY) are presented in table 4.

The overall mean of NL was $4.4 \pm 0.08$ (table 4), which was higher than the estimates reported by Kučević (2019, 2.45) and Sawa and Bogucki (2017, 3.11). However, higher estimates were found by Atil and Khattab (1999, 5.26) and Alhammad (2008, 5.5) on Holstein-Friesian in Egypt.

The lifetime milk production was $6974 \pm 174.47$ $\mathrm{kg}$. This estimate was lower than the estimates reported by Sawa et al. $(2019,22977 \mathrm{~kg})$ on Holstein cows in Poland, Cielava et al., $(2017,37916 \mathrm{~kg})$ on Latvian dairy cows and Kučevićet al. (2019, 18798 $\mathrm{kg}$ ) on Holstein cows in Serbia. Differences among estimates may be due to breed differences, climate and management practices.

The lifetime daily milk yield was $2.3 \pm 0.04 \mathrm{~kg}$. This value was lower than those reported by Sawa et al., (11.3 kg, 2019) on Holstein cows in Poland and found by Cielava et al. (13.2 kg, 2017) on Latvian dairy cows.

Age at first calving (AFC) affected significantly number of lactations (NL), lifetime milk production (LMP) $\quad(p<0.05)$ and lifetime daily milk yield (LDMY) $(\mathrm{p}<0.01)$. The highest values of NL (4.9), LMP $(7610 \mathrm{~kg})$ and LDMY $(2.5 \mathrm{~kg})$ were found for cows of AFCless than or equal 25.4 months, and the lowest values of NL (3.8), LMP (5761 kg) and LDMY $(1.9 \mathrm{~kg})$ were for cows of AFC more than or equalto 34.8 months (table 4). This could be due to the fact that cows calved early had longer PL and more NL, LMP and LDMY compared to those calved late, in addition, there is a negative correlation between age at first calving and number of lactations and lifetime milk production. Similar results were found by Sawa et al., (2019) on Polish HolsteinFriesian and Sawa and Bogucki (2010) on Australian Holstein cows.

Eastham et al., (2018) found that reducing age at first calving was associated with improving
The year of calving had a highly significant effect on PL (table 3). Cows calved during the years between 2006 and 2010 had the minimum value of PL, this could be due to differences in managerial systems from year to another. It is in agreement with Singh et al., (2018), Almasri (2010), and Hammoud et al., (2010) on crossbred Frieswal cows (Friesian $\times$ Sahiwal) in India, Holstein-Friesian cows in Syria and Friesian cows in Egypt, respectively.

The effect of season of calving was nonsignificant on PL, which may be due to the lack of variation in the quality of feed stuffs among seasons, which is in agreement with Almasri (2010).

reproductive performance and increasing of number of lactations on Holstein and Holstein-Friesian cows in the UK.

Zavadilová and Štípková (2013) concluded that Holstein cows had early age at first calving had a good fertility trait, so those cows produced a greater number of lactations during their productive life. The authors found that late age at first calving (33 to 46 months) had worse fertility traits, so those cows produced a smaller number of lactations.

On the contrary, Krpalkova et al. (2017) found that age at first calving had no significant effect on the number of lactations on Holstein and Czech Fleckvieh breed.

The effect of first lactation milk yield on the NL was nonsignificant, while, it affected significantly $(\mathrm{p}<0.01)$ LMP and LDMY (table 4). This result was in agreement with Sawa and Krezel-Czopek (2009). While Sawa and Bogucki (2017) concluded that cows produced in the first lactation more than $11000 \mathrm{~kg}$ milk had a smaller number of lactations (2.3).

The lifetime milk production and lifetime daily milk yieldwere increased by increasing first lactation milk yield (table 4), where cows produced greater than $2400 \mathrm{~kg}$ milk yield in first lactation had lifetime milk production equals $10251 \mathrm{~kg}$ and LDMY equals $3.4 \mathrm{~kg}$. Cows produced less than $560 \mathrm{~kg}$ milk yield in the first lactation had the lowest values of LMP (4471 kg) and LDMY (1.4 kg). This result indicated that first lactation milk yield could be used for prediction of the lifetime milk production of a cow. Tekerli and Kocak (2009) and Sawa and KrezelCzopek (2009) arrived at the same conclusion.

Year of calving had a highly significant effect on the number of lactations, lifetime milk production and lifetime daily milk yield $(\mathrm{p}<0.01)$ (table 4$)$. This could be due to differences in managerial systems from year to another. While the effect of season of calving on the same traits was nonsignificant (table 4). Hammoud et al. (2010) on Friesian cows in Egypt,Almasri (2010) on Holstein-Friesian cows in Syria and Singh et al., (2018) on Frieswal cows (Friesian $\times$ Sahiwal) in India obtained the same conclusion. 
Table 4. Least squares means and standard error $(\mathrm{LSM} \pm \mathrm{SE})$ of number of lactations, lifetime milk production (LMP) and lifetime daily milk yield (LDMY)

\begin{tabular}{|c|c|c|c|}
\hline Classification $^{1}$ & $\begin{aligned} \text { Number } & \text { of } \\
\text { lactations } & (\mathrm{No})\end{aligned}$ & $\begin{array}{l}\text { Lifetime milk } \\
\text { production }(\mathrm{kg}) \\
(\mathrm{LSM} \pm \mathrm{SE})\end{array}$ & $\begin{array}{l}\text { Lifetime daily milk yield (kg) } \\
\qquad(\mathrm{LSM} \pm \mathrm{SE})\end{array}$ \\
\hline Overall mean & $4.4 \pm 0.08$ & $6974 \pm 174.47$ & $2.3 \pm 0.04$ \\
\hline $\begin{array}{l}\text { Age at first calving } \\
\text { (month) }\end{array}$ & $*$ & $*$ & $* *$ \\
\hline$\leq 25.4$ & $4.9^{b} \pm 0.35$ & $7610^{b} \pm 715$ & $2.5^{\mathrm{b}} \pm 0.16$ \\
\hline $25.5-28.6$ & $4.5^{\mathrm{b}} \pm 0.19$ & $7247^{b} \pm 394$ & $2.4^{\mathrm{b}} \pm 0.09$ \\
\hline $28.7-31.7$ & $4.5^{\mathrm{b}} \pm 0.15$ & $7459^{b} \pm 315$ & $2.3^{\mathrm{b}} \pm 0.07$ \\
\hline $31.8-34.7$ & $4.4^{\mathrm{b}} \pm 0.20$ & $6791^{\mathrm{ab}} \pm 403$ & $2.2^{\mathrm{ab}} \pm 0.09$ \\
\hline$\geq 34.8$ & $3.8^{\mathrm{a}} \pm 0.21$ & $5761^{\mathrm{a}} \pm 430$ & $1.9^{\mathrm{a}} \pm 0.09$ \\
\hline $\begin{array}{c}\text { First lactation milk } \\
\text { yield }(\mathrm{kg})\end{array}$ & NS & $* *$ & $* *$ \\
\hline$<560$ & $4.3^{\mathrm{a}} \pm 0.18$ & $4471^{\mathrm{a}} \pm 373$ & $1.4^{\mathrm{a}} \pm 0.08$ \\
\hline $560-1119$ & $4.5^{\mathrm{a}} \pm 0.17$ & $5772^{\mathrm{b}} \pm 348$ & $1.8^{\mathrm{b}} \pm 0.08$ \\
\hline $1120-1679$ & $4.7^{\mathrm{a}} \pm 0.20$ & $6955^{c} \pm 412$ & $2.2^{\mathrm{c}} \pm 0.09$ \\
\hline $1680-2400$ & $4.3^{\mathrm{a}} \pm 0.21$ & $7420^{c} \pm 433$ & $2.5^{\mathrm{d}} \pm 0.10$ \\
\hline$>2400$ & $4.3^{\mathrm{a}} \pm 0.29$ & $10251^{\mathrm{d}} \pm 596$ & $3.4^{\mathrm{e}} \pm 0.13$ \\
\hline $\begin{array}{l}\text { Year of calving } \\
\text { (periods) }\end{array}$ & $* *$ & $* *$ & $* *$ \\
\hline 1981-1985 & $4.5^{\mathrm{b}} \pm 0.23$ & $6798^{\mathrm{ab}} \pm 482$ & $2.1^{\mathrm{a}} \pm 0.11$ \\
\hline $1986-1990$ & $5.3^{\mathrm{c}} \pm 0.24$ & $7877^{\mathrm{a}} \pm 501$ & $2.3^{\mathrm{ab}} \pm 0.11$ \\
\hline 1991-1995 & $4.6^{\mathrm{b}} \pm 0.23$ & $6570^{\mathrm{ab}} \pm 467$ & $2.1^{\mathrm{a}} \pm 0.10$ \\
\hline $1996-2000$ & $4.6^{\mathrm{b}} \pm 0.23$ & $7734^{b} \pm 482$ & $2.6^{\mathrm{b}} \pm 0.11$ \\
\hline 2001-2005 & $4.4^{\mathrm{b}} \pm 0.20$ & $7174^{b} \pm 403$ & $2.3^{\mathrm{ab}} \pm 0.09$ \\
\hline 2006-2010 & $3.3^{\mathrm{a}} \pm 0.21$ & $5690^{\mathrm{a}} \pm 423$ & $2.2^{\mathrm{a}} \pm 0.09$ \\
\hline Season of calving & NS & NS & NS \\
\hline Winter & $4.4^{\mathrm{a}} \pm 0.20$ & $7294^{\mathrm{a}} \pm 416$ & $2.4^{\mathrm{a}} \pm 0.09$ \\
\hline Spring & $4.3^{\mathrm{a}} \pm 0.17$ & $6749^{\mathrm{a}} \pm 348$ & $2.2^{\mathrm{a}} \pm 0.08$ \\
\hline Summer & $4.4^{\mathrm{a}} \pm 0.18$ & $6648^{\mathrm{a}} \pm 366$ & $2.2^{\mathrm{a}} \pm 0.08$ \\
\hline Autumn & $4.6^{\mathrm{a}} \pm 0.19$ & $7204^{\mathrm{a}} \pm 392$ & $2.3^{\mathrm{a}} \pm 0.09$ \\
\hline
\end{tabular}

$1=$ within each classification, means not followed by the same letter differ significantly at $5 \%$ level;

Number of records $=605 ; *(\mathrm{p}<0.05) ; *(\mathrm{p}<0.01)$; NS $=$ not significant

\section{Correlation Coefficients :}

The correlation coefficients between each of AFC and FMY with PL, LMP and LDMY are presented in table 5. The correlation coefficients between AFC and each of PL and NL were negative and highly significant $(\mathrm{p}<0.01)$. Sawa et al. (2019) found that the correlation coefficients between AFC and each of
PL, LMP and NL were $-0.08,-0.11$ and -0.099 , respectively.

The correlation coefficients between FMY and each of LMP and LDMY were positive and highly significant $(\mathrm{p}<0.01)$. Sadek et al. (2009) found that the correlation coefficient between FMY and PL was 0.2 on Holstein cattle in Egypt. Teke and Murat 
(2013) found that the correlation coefficient between FMY and LMP was positive and significant (0.12).
While, Sawa and Krezel-Czopek (2009) found that the correlation coefficient between FMY and NLwas positive and significant (0.10).

Table 5. Correlation Coefficients between each of age at first calving and first lactation milk yield with productive life traits

\begin{tabular}{lcc}
\hline & \multicolumn{2}{c}{ Coefficient of correlation } \\
\cline { 2 - 3 } Productive life traits & Age at first calving (month) & First lactation milk yield (kg) \\
\hline Productive life (month) & $\mathbf{- 0 . 1 8 0 * *}$ & 0.030 \\
Lifetime milk production $(\mathbf{k g})$ & -0.067 & $\mathbf{0 . 3 7 3} * *$ \\
Lifetime daily milk yield $(\mathrm{kg})$ & -0.051 & $\mathbf{0 . 5 4 2} * *$ \\
Number of lactations & $\mathbf{- 0 . 1 2 6 * *}$ & 0.009 \\
\hline
\end{tabular}

Number of records $=605 ; * *(\mathrm{p}<0.01)$.

\section{CONCLUSION}

It could be concluded that the optimum age at first calving of Syrian shami heifers was less than, or equal to, 25 months to achieve the maximum lifetime milk production, the maximum LDMY and the number of lactations. First lactation milk yield reflected the production capacity of Shami cows in subsequent lactations.

\section{REFERENCES}

Abou-Bakr., S.2009. Genetic and phenotypic parameters of some lifetime and longevity traits in Holstein cows of commercial farm in Egypt. Egyptian J. Anim. Prod.46(1):11-18.

Alhammad,H.O., 2008. A genetic study of lifetime performance in Holstein Friesian cattle in Egypt. Ph.D. Thesis Fac. Of Agric., Cairo University, Egypt.

Almasri., O. 2010. Analysis Study for the Productive and Reproductive Traits of Holstein Friesian Cattle at Kharabo Dairy Farm. Master's thesis. Damascus University Syria.

Atil, H. and A.S. Khattab, 1999. Lifetime production and longevity of Holstein Friesian cows in relation to their sire transmitting ability. Pakistan J. Biological Sci. 2(1):69-73.

Brzozowski, P, W. Empel, K. Zdziarski, and H. Grodzki. 2003. Influence of cows' health and their milk yield during first lactation on their productive life and life-time milk yield. Polish Vet Med. 59: 626-29.

Caetano S.L, G.J. Rosa, R.P. Savegnago, S.B. Ramos, P.A. Bernardes, L.A. Bezzera, R.B. Lôbo, C.C. de Paz, and D.P. Munari. 2017. Estimation of genetic parameters for longevity considering the cow's age at last calving. J. Appl. Genetics. 58: 103-109.

Cielava L., D. Jonkus, and L. Paura. 2017. The effect of cow reproductive traits on lifetime productivity and longevity. World Academy of Science, Engineering and Technology, International Science Index 123, International Journal of
Biological, Biomolecular, Agricultural, Food and Biotechnological Engineering. 11: 220-223.

Coffey, M. P., J. Hickey and S. B. Stone. 2006. Genetic aspects of growth of Holstein-Friesian dairy cows from birth to maturity. Journal of Dairy Science. 89: 322-329.

Curran RD, Weigel KA, Hoffman PC, Marshall JA, Kuzdas CK and Coblentz WK 2013. Relationships between age at first calving; herd management criteria; and lifetime milk, fat, and protein production in Holstein cattle. The Profes sional Animal Scientist. 29: 1-9.

Eastham, N. T., A. Coates, P. Cripps, H. Richardson, R. Smith, and G. Oikonomou. 2018. Associations between age at first calving and subsequent lactation performance in UK Holstein and Holstein-Friesian dairy cows. Plos one 13(6): e0197764.https://doi.org/10.1371/journal. pone.0197764.

Evans, R.D., M. Wallace, D. J. Garrick, P. Dillon, D. P. Berry, and V. Olori. 2006. Effects of calving age, breed fraction and month of calving on calving interval and survival cross parties in Irish spring-calving dairy cows. Lives. Sci. 100: 216230.

Hammoud, M.H., S. Z. El-Zarkouny, and E. Z. M. Oudah.2010. Effect of sire, age at first calving, season and year of calving and parity on reproductive performance of Friesian cows under semiarid conditions in Egypt. Archiva Zootechnica.13(1): 60-82.

Herlihy, M.M., M. A. Crowe, D. P. Berry, M.G. Diskin and S.T. Butler .2013. Factors associated with fertility outcomes in cows treated with protocols to synchronize estrus and ovulation in seasonal-calving, pasture-based dairy production systems. J. Dairy Sci. 96: 1485-1498.

Hoffman, P.C., C.R. Sims on and M. Wattiaux. 2006. Effect of a limit feeding regimen on growth and fecal excretion of gravid Holstein heifers. J. Dairy Sci. 90(2):946-954.

Januś., E. and D. Borkowska. 2004. Relationship between milk yield in the first lactation and the 
indices of production traits fertility performance length and the reasons for culling cows. App Sci Rep Polish Soc Anim Prod. 74: 103-9.

Janus, E., and D. Borkowska .2012. Correlations between milk yield in primiparous PHF cows and selected lifetime performance and fertility indicators as well as reasons for culling. Acta Sci. Pol. Zoot. 11: 23-32.

Krpalkova L., J. Syrucek, J. Kvapilik, and J. Burdych. 2017. Analysis of milk production, age of first calving, calving interval and economic parameters in dairy cattle management, Mljekarstvo. 67: 58-70.

Kučević, D., S. Dragin, I. Pihler, K. Čobanović, T. Papović, V. Gantner and M. Mirkov.2019. Effect of age at first calving and other non-genetic factors on longevity and production traits in Holstein cattle under Vojvodina Province condition, Serbia.Indian journal animal research.10:1-4.

Ojango, J., V. Ducrocq and G. E. Pollott. 2005. Survival analysis of factors affecting culling early in the productive life of Holstein-Friesian cattle in Kenya. Livestock Production Science. 92(3):317322.

Sadek, M.H., A.A. Halawa, A.A. Ashmawy and M.F. Abdel Glil .2009. Genetic and phenotypic parameters estimation of first lactation, life-time yield and longevity traits in Holstein cattle. Egypt. J. Genet. Cyt. 38: 127-136.

Sawa, A. 2011. Functional traits and their role in contemporary cattle breeding, part I: longevity of cows, prolonged lactations and urea level in cow milk. Prz. Hod. 2: 8-13.

Sawa, A. and M. Bogucki. 2017. Longevity of cows depending on their first Lactation yield and herd production Level. Ann. Anim. Sci. 17(4): 11711183.

Sawa, A. and M. Bogucki. 2010. Effect of some factors on cow longevity. Arch. Tierzucht, 53: 403-414.
Sawa, A. and S. Krezel-Czopek. 2009. Effect of first lactation milk yield on efficiency of cows in herds with different production levels. Archiv Tierzucht. 52 (1): 7-14.

Sawa, A., K. Siatka and S. Krężel-Czopek. 2019. Effect of age at first calving on first lactation milk yield, lifetime milk production and longevity of cows, Annals of Animal Science, DOI: 10.2478/aoas-2018-0044.

Singh, S., D. Chakraborty, A.K Das, R.K Taggar, N. Kumar and D. Kumar. 2018. Factors affecting lifetime performance traits in frieswal cows. International Journal of Fauna and Biological Studies. 5(3): 203-205.

Teke, B. and Murat, H. 2013. Effect of age at first calving on first lactation milk yield, lifetime milk yield and lifetime in Turkish Holsteins of the Mediterranean Region in Turkey. Bulgarian Journal of Agricultural Science, Agricultural Academy. 19: 1126-1129.

Tekerli M. and S. Koçak .2009. Relationships between production and fertility traits in first lactation and life time performances of Holstein cows under subtropical condition. Arch. Tierz., 52: 364-370.

Tozer, P. R. and A. J. Heinrichs . 2001. What affects the costs of raising replacement dairy heifers: a multiple-component analysis. J. Dairy Sci. 84(8):1836-44.

Wathes, D. C, J. S. Brickell, N. E. Bourne, A. Swali and Z. Cheng. 2008. Factors influencing heifer survival and fertility on commercial dairy farms. Animal. 2: 1135-43.

Wu, J.J., D. C. Wathes, J. S. Brickell, L. G. Yang, Z. Cheng and H. Q. Zhao, 2012. Reproductive performance and survival of Chinese Holstein dairy cows in central China. Anim Prod Sci. Csiro Publishing. 52: 11.

Zavadilová, L. and M. Štípková. 2013. Effectofageat first calving on longevity and fertility traits for Holstein cattle. Czech Journal of Animal Science $58,47-57$.

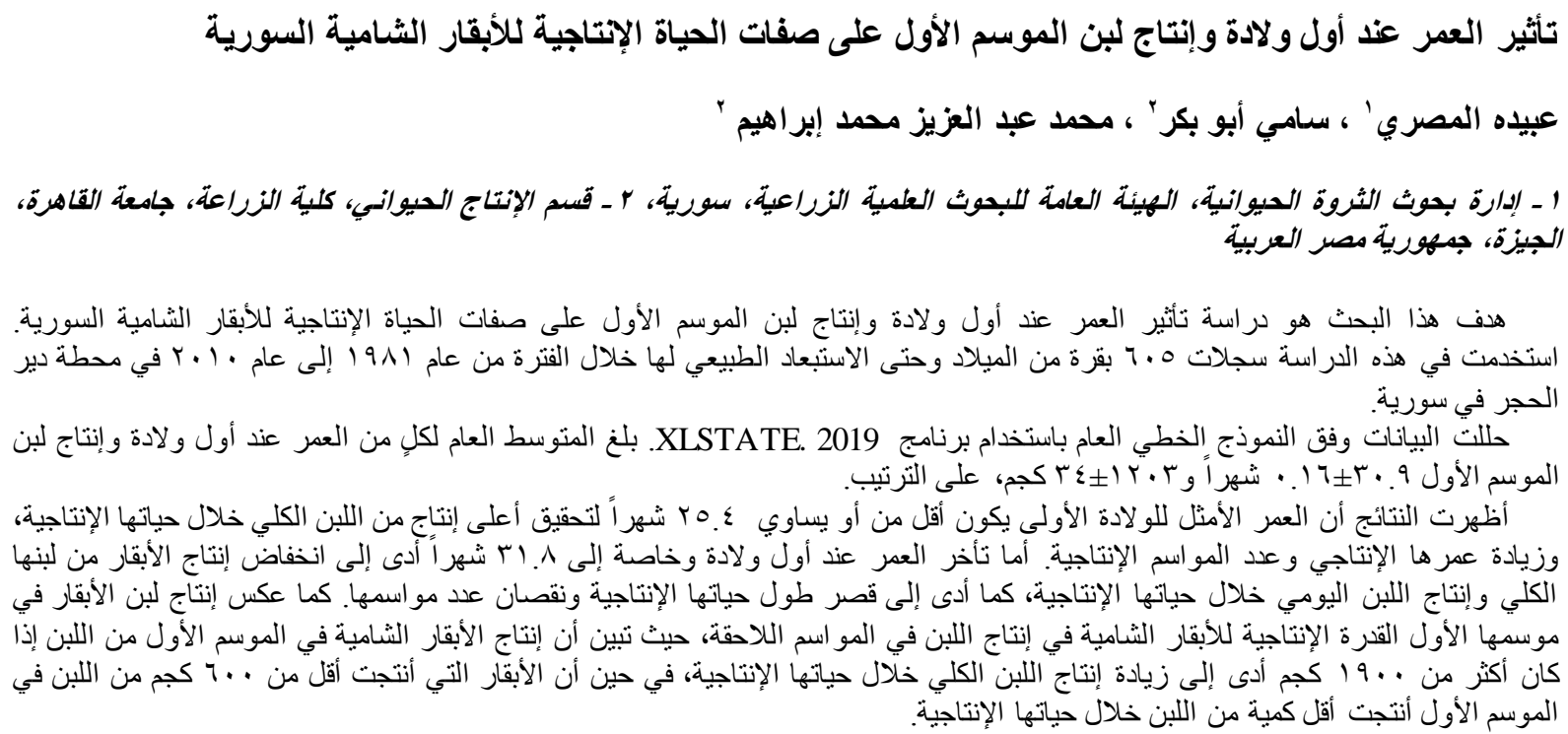

